\title{
A Synthesis of Mobile Ticketing Applications Used by Commuter Railroads in the United States
}

\author{
Jonathan Mesoraca \\ Long Island Rail Road \\ Candace Brakewood \\ University of Tennessee in Knoxville
}

\begin{abstract}
Since 2012, many major commuter railroads have deployed mobile ticketing applications (or "apps") that allow passengers to pay fares directly using their smartphones. In light of this rapid technological change, this research aims to provide a synthesis of the current state of mobile ticketing in the United States. The 14 largest commuter railroads that have launched mobile ticketing apps are compared in four different areas: (1) the ticket validation process; (2) ticket types offered in the mobile app; (3) additional features in the app; and (4) the process for transferring to other modes using the app. The results reveal that all mobile ticketing applications considered in this analysis utilize visual inspection for validation, and that most of them also use quick response $(Q R)$ barcodes to validate tickets. Additionally, many of the commuter rail operators examined offer the majority of the ticket types available via traditional fare media in their mobile ticketing apps. The third dimension revealed a large degree of variation in the availability of additional travel-related features, such as trip planners and schedules, in mobile ticketing apps. Last, only a handful of commuter rail operators have fully integrated transfer policies between commuter rail and other nearby transit modes using mobile ticketing, which is an area that warrants further study. These findings are important for other commuter rail and transit operators that are considering deployment of mobile ticketing systems.
\end{abstract}

Keywords: mobile ticketing, near field communications, short message service, passive ticketing, flash pass

\section{Introduction}

Commuter rail services typically use conductor-validated or proof-of-payment fare collection systems. In a conductor-validated system, riders may buy tickets in advance at ticket windows, vending machines, or

(C) 2018 Jonathan Mesoraca \& Candace Brakewood

https//doi.org/10.5038/2375-0901.21.2.6

ISSN: 1077-291X | Licenced under Creative Commons License Attribution - Noncommercial 4.0

The Journal of Public Transportation is published by the Center for Urban Transportation Research at the University of South Florida 
local retailers and then present their tickets to conductors for validation, or purchase tickets directly from conductors onboard. In a proof-of-payment system, passengers must possess a valid ticket, which is subject to random inspection; this system is an honor system in which riders typically carry prepurchased tickets (Multisystems 2003). Conductor-validated and proof-of-payment methods have been staples in the commuter railroad industry for years, and they primarily rely upon the use of paper tickets. However, since 2012 there has been a dramatic push toward adopting mobile ticketing applications in commuter rail revenue collection systems (Brakewood et al. 2014; Tavilla 2016). A mobile ticketing system enables passengers to purchase tickets directly on their smartphones using a credit card, debit card, or other electronic payment (Sion, Brakewood, and Alvarado 2016). Taking note of these rapid technological changes, this study aims to compile a comprehensive synthesis of the state of mobile ticketing applications (or "apps") used by the largest commuter railroads in the United States.

The paper begins by reviewing prior research on new fare payment systems. Next, the specific objectives of this synthesis are set forth, and the selection criteria used to identify commuter railroads are discussed. Background information about mobile ticketing launches and app utilization is then shown for each operator. A comparison of the four dimensions of mobile ticketing applications follows, along with an identification of key trends. Finally, concluding remarks and suggestions for future research are presented.

\section{Prior Research}

Currently there are four primary types of mobile technology used for ticketing by transit operators: (1) near field communications, (2) short message service, (3) passive ticketing, and (4) flash pass and/or quick response barcode (Wallischeck 2015). The following sections briefly describe each type, following the framework of Wallischeck (2015).

\section{Near Field Communications}

Near field communications (NFC) is a mobile payment technology that employs radio frequency communication to exchange data securely (Wallischeck 2015; Georggi et al. 2017). In this type of fare collection system, passengers can "tap" fare barriers with contactless readers and enter using a smartcard or NFC-enabled smartphone. While this system has been implemented successfully by heavy rail systems, such as the Chicago Transit Authority, commuter railroads in the United States have yet to accept it. The major reason for this is likely the large capital investment and operating costs needed to transform a barrier-free fare collection system into one with faregates and validation points. Additionally, installing a barrier system involves a significant change in customer experience for most conductor-validated or proof-of-payment systems (Brakewood et al. 2014).

\section{Short Message Service Ticketing}

The second approach to mobile ticketing utilizes short message service (SMS) technology to deliver tickets to cell phones that can receive text messages. To purchase a ticket, a rider sends a text message to the transit operator who then replies with a ticket. The messages sent by riders typically contain a predetermined code that represents the fare for a particular ticket type, and the response message contains fare information and expiration details (Wallischeck 2015). The text message "ticket" is then presented to conductors or inspectors for validation. This ticketing scheme may present a more equitable scenario for riders since a smartphone is not required. However, its use has been limited to European cities and it has not been widely adapted in the United States. 


\section{Passive Mobile Ticketing}

The third type of mobile technology used for transit ticketing involves passive interaction between the rider's smartphone and readers located at fare barriers or other points of entry. In a passive environment, riders do not have to physically interact with their phones in any way. Instead, the readers at fare barriers automatically detect an enabled smartphone and record the time and location that a rider enters/exits the system (Wallischeck 2015). Passive mobile technology typically employs Bluetooth Smart or Bluetooth Low Energy, which can be an appealing alternative to NFC communications because of its ability to be completely hands-free. However, like NFC, its adoption by commuter railroads is unlikely due to the expensive retrofitting required for fare collection systems that are currently barrier-free.

\section{Flash Pass or Quick Response Barcode}

The fourth type of mobile technology used for transit ticketing is a smartphone application that emulates paper tickets (Wallischeck 2015). Passengers purchase a ticket by entering their desired origin/destination and ticket type into the smartphone app and then pay using a credit card, debit card, or other electronic payment method. Once the ticket purchase is complete, the ticket is stored on the smartphone or in cloud servers and can be viewed and activated as needed (Tavilla 2015). Prior to travel, riders must activate their tickets to ensure they are valid.

Conductors or inspectors validate tickets by two different methods. The first is visual inspection, in which the conductor inspects the smartphone ticketing screen for a dynamic feature. The dynamic feature is most frequently a color-changing scheme that depends on the route and time of day. Other features may include visible timestamps, moving animations, or countdown clocks. Not only do these features enable conductors to easily inspect tickets, but they also double as fraud protection by making it difficult to screenshot, record, or duplicate mobile tickets (Tavilla 2015). An example of this type of mobile ticketing app can be seen in Figure 1, which shows the app used by the commuter railroads in the New York City region.

The second validator method requires passengers to display a quick response $(\mathrm{QR})$ barcode on an active ticket that can be scanned by the conductor with a handheld validator or smartphone. While this method may be more secure, it requires additional steps that slow down the verification process.

Mobile ticketing applications that employ visual or barcode inspections work well with the barrier-free fare collection systems typically used in the commuter rail industry (Tavilla 2015). In light of this, many commuter rail operators have chosen this type of technology and deployed it in their fare collection systems. This paper focuses on mobile ticketing applications that use flash pass and/or QR barcode technology, and provides a systematic comparison of these applications. 


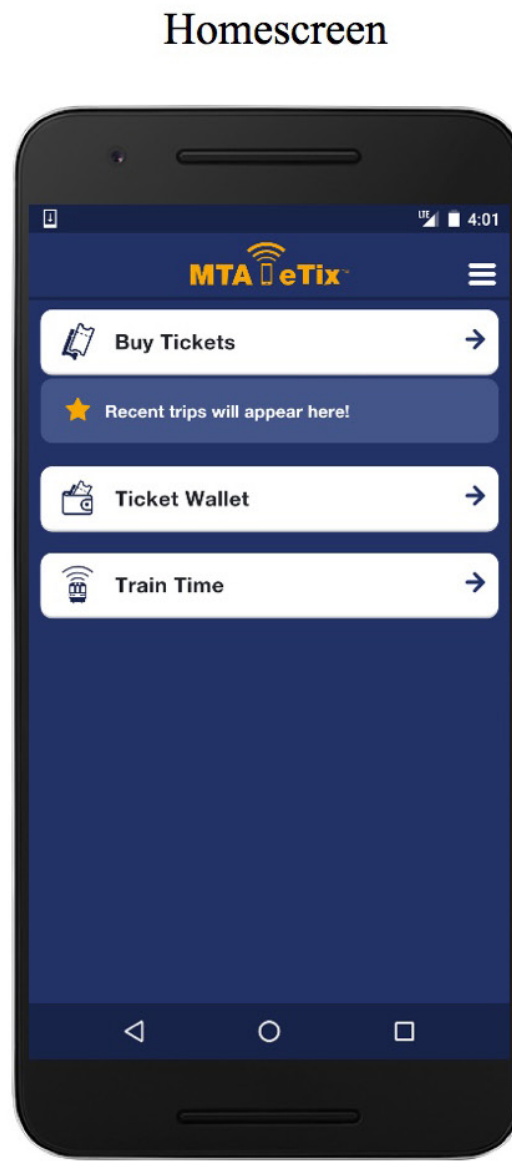

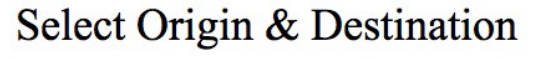

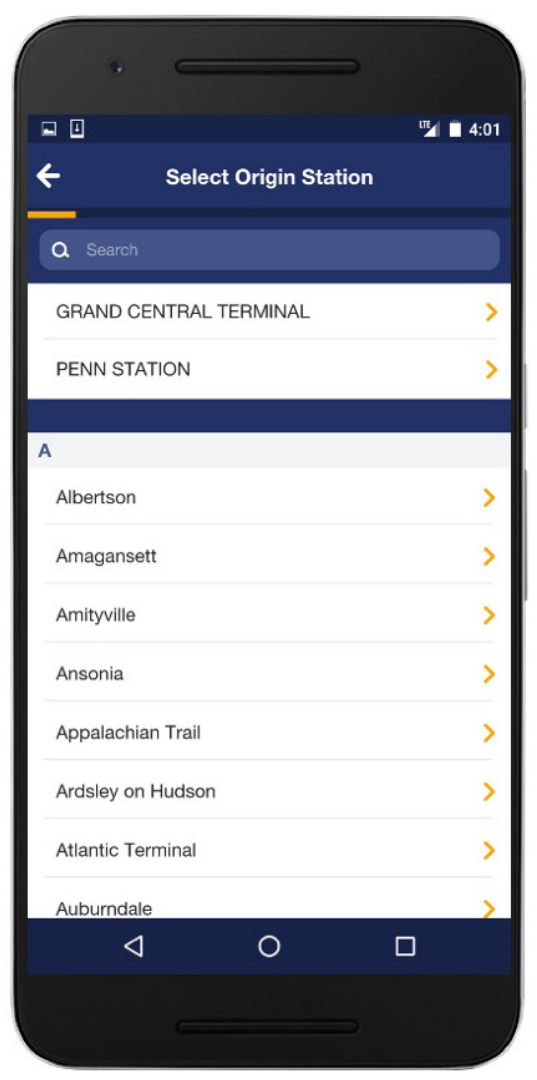

Select Ticket Type

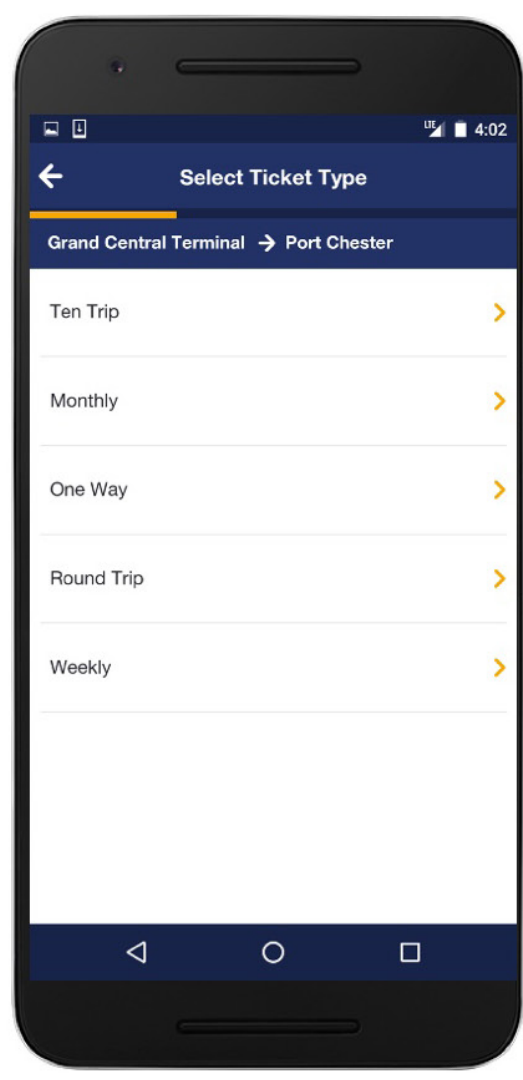

Activated Ticket

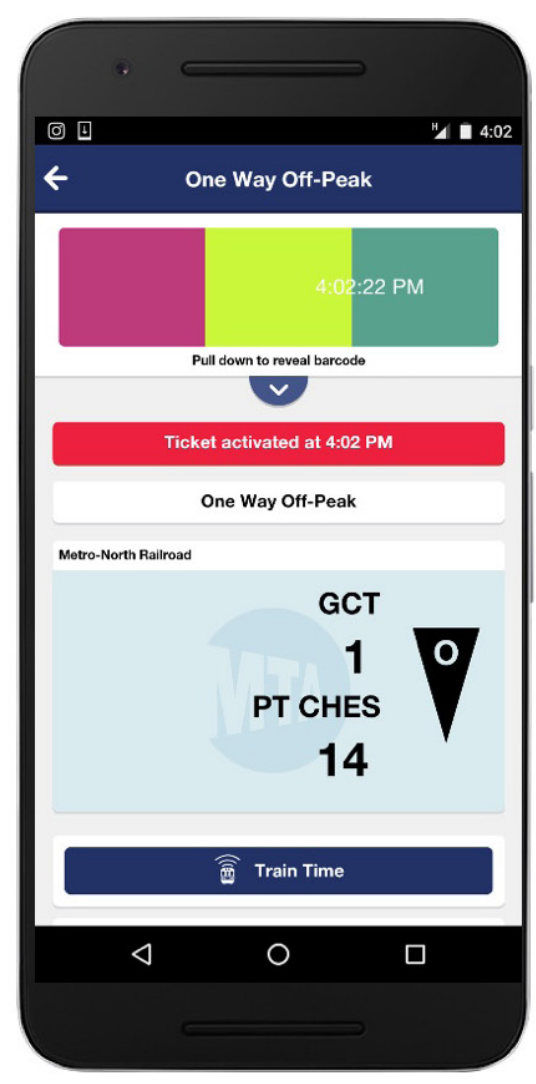

\section{FIGURE 1.}

Screenshots of a flash pass mobile ticketing application (MTA, New York; eTix Android App, Version 3.2.7) 


\section{Objectives}

The objective of this study is to synthesize the current state of practice of mobile ticketing applications used by commuter railroads in the United States. This synthesis will compare mobile ticketing apps along four dimensions: validation process, ticket types, application features, and transfer processes. Validation process refers to the method by which a mobile ticket can be authenticated, such as visual inspection or QR codes. The second dimension, ticket types, compares ticket offerings for each mobile application with those offered by traditional fare media. The third dimension is application features, and this pertains to additional travel-related features in each mobile ticketing application. The fourth dimension examines the transfer process between commuter rail and alternative forms of nearby transit services when using a mobile ticket versus traditional fare media.

By systematically comparing existing mobile ticketing applications, this analysis identifies agency leaders who provide a high level of functionality in these applications. The synthesis also provides an understanding of the current state of practice to other commuter rail operators that have not launched mobile ticketing applications but are considering it.

\section{Selection Criteria}

The selection of commuter rail operators for this research was based on the 2015 American Public Transportation Association Fact Book (Neff and Dickens 2015). Table 37 of the fact book lists the largest commuter and hybrid railroads in the nation by unlinked passenger trips using 2013 ridership data. This list was then narrowed down to the 14 commuter rail operators that provide mobile ticketing as a fare payment option. These 14 operators use a total of 12 mobile ticketing applications because 4 of them share applications ( 2 in the New York City region and 2 in Texas). The Long Island Rail Road and Metro North Commuter Railroad share the Metropolitan Transportation Authority's eTix application, and Dallas Area Rapid Transit and Denton County Transportation Authority share the GoPass application. Throughout this paper, these four commuter rail operators (two in New York and two in Texas) will be combined because they utilize the same application.

\section{Background on Mobile Ticketing Launches and App Utilization}

The 14 commuter rail operators considered in this analysis have all launched mobile ticketing applications since 2012. As shown in Figure 2, the Massachusetts Bay Transportation Authority (MBTA) of Boston was the pioneer of commuter rail providers in the United States and deployed mobile ticketing in 2012 (Tavilla 2016). Shortly thereafter in 2013, five other agencies (New Jersey Transit [NJT], North County Transit District [NCTD] - San Diego, Dallas Area Rapid Transit [DART], Denton County Transportation Authority [DCTA], and Tri-County Metropolitan Transportation District [TriMet] - Portland) launched mobile ticketing applications (Tavilla 2016; NCTD 2013; Sion, Brakewood, and Alvarado 2016). In 2014, mobile ticketing launched in Indiana and Austin, Texas, with Northern Indiana Commuter Transportation District (NICTD) and Capital Metropolitan Transportation Authority (CapMetro), respectively (Tavilla 2016). The following year brought an additional two deployments with the Virginia Railway Express (VRE) and Metra in Chicago (Tavilla 2016). In 2016, four commuter rail providers (MTA Metro-North [MNR] - New York, MTA Long Island Rail Road [LIRR] - New York, Southern California Regional Rail Authority [Metrolink], and Rio Metro Regional Transit District [RMRTD] New Mexico) launched mobile ticketing applications (Tavilla 2016; SPX Corporation 2016). 


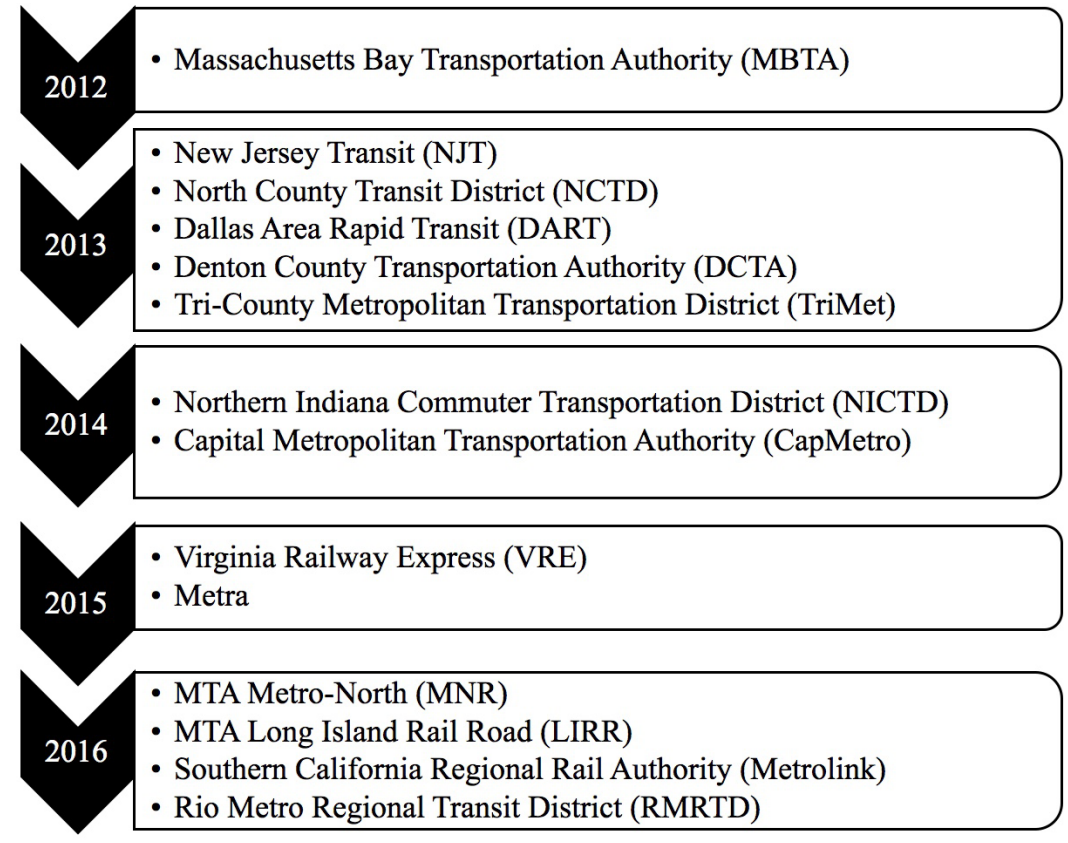

\section{FIGURE 2.}

Timeline of mobile ticketing launches in US commuter railroad systems

These 14 commuter railroads launched the 12 mobile ticketing applications listed in the left column of Table 1. For each launch, the commuter rail operators contracted an app developer. As shown in the center column of Table 1, the notable companies developing mobile ticketing apps in the United States include Masabi, Bytemark, Moovel Transit, CooCoo Transit, and Xerox. Last, the app used for analysis focused on the IOS version unless otherwise noted. Since mobile ticketing applications are updated frequently and features may change between versions, each IOS app version used for the following analysis is listed in Table 1.

\section{TABLE 1.}

Mobile Ticketing Applications for American Commuter Railroad Systems

\begin{tabular}{|c|c|c|}
\hline Application (Agency Name) & App Developer & IOS App Version \\
\hline CapMetro (CapMetro) & Bytemark & 1.158 \\
\hline Coaster (NCTD) & CooCoo Transit & 2.0 .1 \\
\hline GoPass (DART/DCTA) & Moovel Transit (Formerly Unwire) & 1.2 .1 \\
\hline Metrolink (Metrolink) & Masabi & 3.2 .4 \\
\hline MTA eTix (LIRR/MNR) & Masabi & 3.2 .3 \\
\hline mTicket (MBTA) & Masabi & 3.2 .5 \\
\hline MyTix (NJ Transit) & Xerox & 2016.2 .0 \\
\hline RioTicketing (RMRTD) & CooCoo Transit & 1.0 .2 \\
\hline South Shore (NICTD) & Bytemark & 1.147 \\
\hline TriMet Tickets (TriMet) & Moovel Transit & 1.7 .1 \\
\hline Ventra (Metra) & Moovel Transit with Cubic & 1.3 .1 \\
\hline VRE Mobile (VRE) & Moovel Transit & 1.7 .3 \\
\hline
\end{tabular}


To provide additional background on these apps, the approximate number of users on the Android platform was compiled from Google Play downloads and is shown in Figure 3. Since iTunes does not show the number of downloads, downloads via the Android version were examined in this section, whereas the subsequent analyses focus on IOS app versions. As can be seen in Figure 3, one commuter railroad (RMRTD) has only 5001,000 downloads on Google Play, three (NCTD, NICTD, VRE) have 10,000-50,000 downloads, another three (CapMetro, Metrolink, LIRR/MNR) have 50,000-100,000 downloads, and five (DART/DCTA, MBTA, NJ TRANSIT, TriMet, Metra) have 100,000-500,000 downloads on Google Play. These differences in utilization could be due to many factors, such as launch date, ridership levels, and ticketing features available.

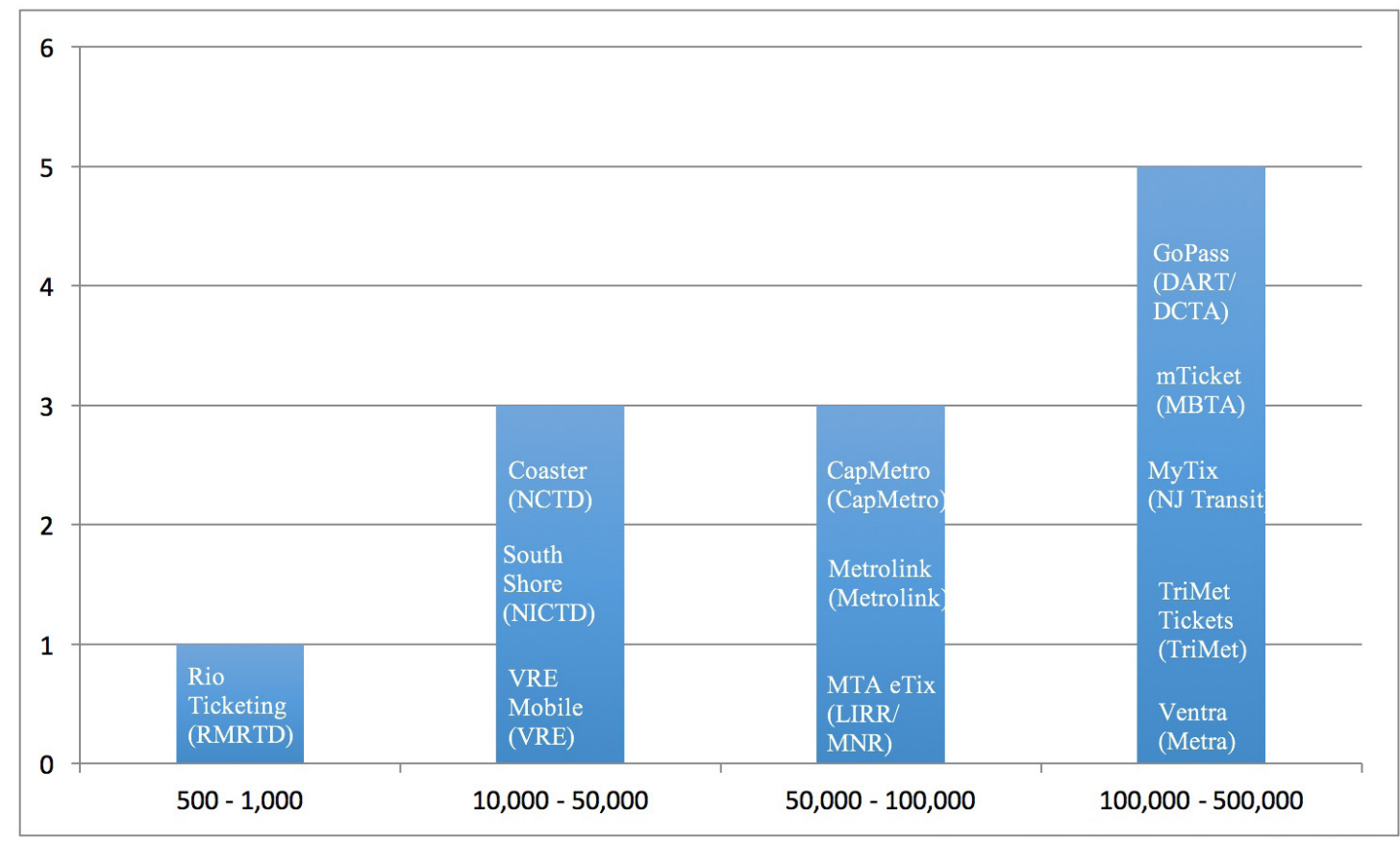

Source: Google Play, December 2016.

\section{FIGURE 3.}

Approximate number of Android application users

\section{Comparison of Mobile Ticketing Applications}

This section presents a comparison of the following four dimensions of mobile ticketing applications and their corresponding fare policies: the validation process, ticket types, application features, and the transfer process.

\section{Dimension 1: Validation Process}

The two validation types are visual inspection and $Q R$ barcode scan. As previously discussed, visual inspection involves the conductor or inspector checking the mobile ticketing screen for a dynamic feature, such as a colorchanging scheme that varies by time of day and route. The second method requires passengers to display a $Q R$ barcode on an active ticket that can be scanned by the conductor with a hand-held validator or smartphone. Table 2 presents the mobile ticketing validation process used by each agency in the analysis, where $Y$ indicates a method currently utilized and $N$ designates that the agency does not support that validation process. 
TABLE 2.

Validation Process

\begin{tabular}{|c|c|c|}
\hline Application/Agency Name & Barcode & Visual \\
\hline CapMetro (CapMetro) & $\mathrm{Y}$ & $\mathrm{Y}$ \\
\hline Coaster (NCTD) & $\mathrm{Y}$ & $\mathrm{Y}$ \\
\hline GoPass (DART/DCTA) & $\mathrm{N}$ & $\mathrm{Y}$ \\
\hline Metrolink (Metrolink) & $\mathrm{Y}$ & $\mathrm{Y}$ \\
\hline MTA eTix (LIRR/MNR) & $\mathrm{Y}$ & $\mathrm{Y}$ \\
\hline mTicket (MBTA) & $\mathrm{Y}$ & $\mathrm{Y}$ \\
\hline MyTix (NJ Transit) & $\mathrm{Y}$ & $\mathrm{Y}$ \\
\hline RioTicketing (RMRTD) & $\mathrm{Y}$ & $\mathrm{Y}$ \\
\hline South Shore (NICTD) & $\mathrm{N}$ & $\mathrm{Y}$ \\
\hline TriMet Tickets (TriMet) & $\mathrm{Y}$ & $\mathrm{Y}$ \\
\hline Ventra (Metra) & $\mathrm{Y}$ & $\mathrm{Y}$ \\
\hline VRE Mobile (VRE) & $\mathrm{Y}$ & $\mathrm{Y}$ \\
\hline
\end{tabular}

While all applications considered in this research currently employ visual inspection of mobile tickets, only two (GoPass and South Shore) do not support QR barcode scanning as an additional means of validation. Although most of the applications considered have a barcode feature, it is unclear how often the barcode is actually used for validation. In some cases, it may only be used if there is a question regarding the validity of a visually inspected ticket; in others, operators may choose to scan a random number of tickets. This is something that should be explored further in future research.

\section{Dimension 2: Ticket Types}

The ticket types selected for comparison were broken down into three categories: (1) per trip tickets, which include adult one-way tickets, adult round-trip tickets, and ten-trip tickets; (2) period passes, which is composed of daily, weekly, and monthly tickets; and (3) miscellaneous, for discounted fares applied to the elderly, disabled, military, students, or children, and any other ticket offerings that did not meet the selected criteria. Table 3 presents a comparison of the ticket types offered in each agency's mobile application to those offered using traditional fare media, such as paper tickets. In Table 3, $Y$ indicates that the ticket type is available for purchase in the mobile application, NM designates that the ticket type is not available on the mobile application but is offered by the agency via other media, such as paper tickets, and $N$ signifies that the agency does not offer this ticket type via any means. 


\section{TABLE 3.}

Ticket Types

\begin{tabular}{|c|c|c|c|c|c|c|c|c|c|c|c|c|}
\hline \multirow[b]{2}{*}{$\begin{array}{c}\text { Application/Agency } \\
\text { Name }\end{array}$} & \multirow[b]{2}{*}{$\begin{array}{l}\text { \# Tix } \\
\text { Mobile }\end{array}$} & \multirow[b]{2}{*}{$\begin{array}{l}\text { \# Tix } \\
\text { Total }\end{array}$} & \multirow[b]{2}{*}{$\begin{array}{l}\% \text { Avail } \\
\text { Mobile }\end{array}$} & \multicolumn{3}{|c|}{ Per Trip Tickets } & \multicolumn{3}{|c|}{ Period Passes } & \multicolumn{3}{|c|}{ Miscellaneous } \\
\hline & & & & $\begin{array}{l}\text { Adult } \\
\text { One-Way }\end{array}$ & $\begin{array}{c}\text { Adult } \\
\text { Round-Trip }\end{array}$ & $\begin{array}{l}\text { Ten- } \\
\text { Trip }\end{array}$ & Daily & Weekly & Monthly & $\begin{array}{l}\text { Discounted (Elderly, } \\
\text { Disabled, Military, } \\
\text { Student, Children) }\end{array}$ & Other & Remarks \\
\hline CapMetro (CapMetro) & 4 & 5 & $80 \%$ & Y & $\mathrm{N}$ & $\mathrm{N}$ & Y & Y & Y & NM & $\mathrm{N} / \mathrm{A}$ & \\
\hline Coaster (NCTD) & 3 & 5 & $60 \%$ & $\mathrm{Y}$ & $\mathrm{Y}$ & $\mathrm{N}$ & NM & $\mathrm{N}$ & NM & Y & $\mathrm{N} / \mathrm{A}$ & \\
\hline GoPass (DART/DCTA) & 6 & 7 & $86 \%$ & $\mathrm{~N}$ & $\mathrm{~N}$ & N & Y & Y & Y & $Y^{*}$ & $\begin{array}{l}2 \text { Hour, Midday, } \\
\text { Annual Pass (NM) }\end{array}$ & $\begin{array}{c}\text { "Student } \\
\text { discount not on } \\
\text { mobile. }\end{array}$ \\
\hline Metrolink (Metrolink) & 6 & 6 & $100 \%$ & Y & Y & $\mathrm{N}$ & $\mathrm{N}$ & Y & Y & Y & Weekend Day Pass & \\
\hline MTA eTix (LIRR/MNR) & 9 & 9 & $100 \%$ & Y & Y & Y & $\mathrm{N}$ & Y & Y & Y & $\begin{array}{l}\text { CityZone, Family, } \\
\text { Peak/Off-Peak Fares }\end{array}$ & \\
\hline mTicket (MBTA) & 4 & 5 & $80 \%$ & Y & $\mathrm{Y}$ & $Y^{*}$ & $\mathrm{~N}$ & $\mathrm{~N}$ & $Y^{* *}$ & NM & $\mathrm{N} / \mathrm{A}$ & $\begin{array}{l}{ }^{*} \text { Only available } \\
\text { on mobile. }{ }^{* *} \text { No } \\
\text { subway/bus pass } \\
\text { included for } \\
\text { mobile purchase. }\end{array}$ \\
\hline MyTix (NJ Transit) & 5 & 6 & $83 \%$ & Y & $\mathrm{N}$ & NM & $\mathrm{N}$ & Y & Y & Y & Family Super Saver & \\
\hline RioTicketing (RMRTD) & 5 & 5 & $100 \%$ & Y & $\mathrm{N}$ & N & Y & $\mathrm{N}$ & Y & Y & Annual Pass & \\
\hline South Shore (NICTD) & 5 & 5 & $100 \%$ & Y & $\mathrm{N}$ & Y & N & $\mathrm{N}$ & Y & Y & 25 Rides & \\
\hline $\begin{array}{l}\text { TriMet Tickets } \\
\text { (TriMet) }\end{array}$ & 6 & 7 & $86 \%$ & $\mathrm{~N}$ & $\mathrm{~N}$ & N & Y & Y & Y & Y & $\begin{array}{l}2.5 \text { Hour ( } 1 \text { or } 10), \\
14 \text { Day, Annual Pass } \\
(N M)\end{array}$ & \\
\hline Ventra (Metra) & 5 & 5 & $100 \%$ & Y & $\mathrm{N}$ & Y & $\mathrm{N}$ & $\mathrm{N}$ & Y & Y & Weekend Pass & \\
\hline VRE Mobile (VRE) & 6 & 7 & $86 \%$ & Y & $\mathrm{N}$ & Y & Y & $Y^{\varsigma}$ & Y & NM & Amtrak Step-Up & $\begin{array}{l}\$ 5 \text {-day pass, no } \\
\text { weekend service. }\end{array}$ \\
\hline
\end{tabular}

Key: $Y=$ Yes (Offered and Mobile); NM = Offered but Not on Mobile; $N=$ Agency Does Not Offer 
To gauge how well each mobile ticketing application captures each operator's fare policy, a percentage of in-mobile ticket types to all available types was calculated. This was done by first calculating the "\# Tix Mobile" column shown in Table 3, in which all ticket types with a $Y$ were summed. Then, the "\# Tix Total" column was formulated by adding up all ticket types with a $Y$ or NM; entries with an $N$ were not included. The results demonstrate that overall these commuter rail mobile ticketing applications do a good job in offering the full fare policy. Five applications (Metrolink, MTA eTix, Rio Ticketing, South Shore, and Ventra) offered 100\% of ticket types, and therefore provide the same experience as for passengers purchasing tickets by conventional media. Conversely, only the Coaster application used by NCTD failed to offer at least $80 \%$ of available ticket types offered using conventional media.

\section{Dimension 3: Application Features}

The features selected for comparison were train schedules, route maps, real-time vehicle information, trip planning, service alerts, police information, and other. These features were selected because they are commonly used in mobile ticketing apps (Ali et al. 2017). Table 4 presents a comparison of the travel-related features available within each agency's mobile ticketing application, and these are compared to those offered on the commuter rail operator's website. In Table 4, $Y$ indicates that the feature is available within the mobile application, $W$ designates that the feature is available on the mobile application via redirection to the agency website, $N^{*}$ denotes that the feature is available only on the agency web page, and $N$ signifies that the agency does not offer this feature via any electronic means. 
TABLE 4.

Application Features

\begin{tabular}{|c|c|c|c|c|c|c|c|c|c|c|}
\hline $\begin{array}{l}\text { Application/Agency } \\
\text { Name }\end{array}$ & $\begin{array}{c}\text { In App } \\
\text { Features } \\
(\mathrm{Y}+\mathrm{W})\end{array}$ & $\begin{array}{l}\text { Total } \\
\text { Features }\end{array}$ & $\begin{array}{l}\text { \% Avail } \\
\text { In App }\end{array}$ & $\begin{array}{l}\text { Train } \\
\text { Schedules }\end{array}$ & $\begin{array}{l}\text { Route } \\
\text { Maps }\end{array}$ & $\begin{array}{l}\text { Real-Time } \\
\text { Information }\end{array}$ & $\begin{array}{l}\text { Trip } \\
\text { Planning }\end{array}$ & $\begin{array}{l}\text { Service } \\
\text { Alerts }\end{array}$ & Police & Other \\
\hline CapMetro (CapMetro) & 5 & 7 & $71 \%$ & Y & Y & Y & Y & $\mathrm{Y}$ & $\mathrm{N}$ & Accessibility Info $\left(\mathrm{N}^{*}\right)$, Lost \& Found $\left(\mathrm{N}^{*}\right)$ \\
\hline Coaster (NCTD) & 4 & 7 & $57 \%$ & Y & Y & Y & $\mathrm{N}^{*}$ & $\mathrm{Y}$ & $\mathrm{N}^{*}$ & Accessibility Info $\left(\mathrm{N}^{*}\right)$ \\
\hline GoPass (DART/DCTA) & 5 & 9 & $56 \%$ & $\mathrm{~N}^{*}$ & $\mathrm{~N}^{*}$ & Y & Y & $\mathrm{Y}$ & $\mathrm{N}^{*}$ & $\begin{array}{l}\text { Lyft, Uber, and Zipcar links }(\mathrm{Y}) \text {, events \& } \\
\left.\text { offers }(\mathrm{Y}) \text {, Accessibility Info ( } \mathrm{N}^{*}\right)\end{array}$ \\
\hline Metrolink (Metrolink) & 7 & 8 & $88 \%$ & W & W & $\mathrm{N}$ & $\mathrm{N}$ & W & $\mathrm{N}^{*}$ & $\begin{array}{c}\text { Station Info (W), Lost \& Found (W), } \\
\text { Accessibility Info (W), Uber \& Lyft links (W) }\end{array}$ \\
\hline MTA eTix (LIRR/MNR) & 10 & 10 & $100 \%$ & W & W & W & W & W & W & $\begin{array}{c}\text { Station Info (W), Accessibility/Bike Policies } \\
(\mathrm{W}) \text {, Lost \& Found (W) }\end{array}$ \\
\hline mTicket (MBTA) & 7 & 7 & $100 \%$ & W & W & W & W & W & W & Accessibility Info (W) \\
\hline MyTix (NJ Transit) & 4 & 9 & $44 \%$ & Y & $\mathrm{N}^{*}$ & Y & $\mathrm{Y}$ & $\mathrm{N}^{*}$ & Y & $\begin{array}{c}\text { Station Info }\left(\mathrm{N}^{*}\right) \text {, Accessibility Info }\left(\mathrm{N}^{*}\right) \\
\text { Lost \& Found }\left(\mathrm{N}^{*}\right)\end{array}$ \\
\hline RioTicketing (RMRTD) & 2 & 8 & $25 \%$ & Y & $\mathrm{N}^{*}$ & $\mathrm{~N}$ & $\mathrm{~N}^{*}$ & Y & $\mathrm{N}^{*}$ & $\begin{array}{c}\text { Accessibility Info }\left(\mathrm{N}^{*}\right) \text {, Lost \& Found }\left(\mathrm{N}^{*}\right) \\
\text { Station Info }\left(\mathrm{N}^{*}\right)\end{array}$ \\
\hline South Shore (NICTD) & 3 & 5 & $60 \%$ & Y & $\mathrm{Y}$ & $\mathrm{N}$ & $\mathrm{N}^{*}$ & $\mathrm{Y}$ & $\mathrm{N}^{*}$ & N/A \\
\hline TriMet Tickets (TriMet) & 8 & 9 & $89 \%$ & W & W & W & W & W & $\mathrm{N}^{*}$ & $\begin{array}{l}\text { Accessibility Info (W), Lost \& Found (W), } \\
\text { Station Info (W) }\end{array}$ \\
\hline Ventra (Metra) & 1 & 9 & $11 \%$ & $\mathrm{~N}^{*}$ & $\mathrm{~N}^{*}$ & Y & $N^{*}$ & $\mathrm{~N}^{*}$ & $\mathrm{~N}^{*}$ & $\begin{array}{c}\text { Accessibility Info }\left(\mathrm{N}^{*}\right), \text { Lost \& Found }\left(\mathrm{N}^{*}\right) \\
\text { Zipcar }\left(\mathrm{N}^{*}\right)\end{array}$ \\
\hline VRE Mobile (VRE) & 8 & 8 & $100 \%$ & Y & Y & Y & $\mathrm{N}$ & Y & Y & $\begin{array}{c}\text { Station Info }(Y) \text {, Accessibility Info }(Y) \text {, Lost } \\
\& \text { Found }(Y)\end{array}$ \\
\hline
\end{tabular}

Key: $Y=$ Yes, Feature Offered in App; $W=$ Feature by Linking to Website or Another App; $N^{*}=$ Feature Available on Website; $N=$ Feature Not Offered 
To determine how well each mobile ticketing application did in providing the travel-related features, a percentage of in-mobile features to all available features was calculated. The "In App Features" column was calculated by adding all features with a $Y$ or $W$, and the "Total Features" column was formulated by summing the $Y, W$, or $N^{*}$ entries. Entries with an $N$ were not included. The results were varied, indicating that some applications provide many features beyond mobile ticketing, whereas others do not. Notably, Metrolink, MTA eTix, MBTA mTicket, and TriMet Tickets fared well in these calculations because the features in these applications redirected users to the commuter rail operators' websites.

\section{Percentage Ticket Types and Application Features}

Figure 4 is a visualization of the results from the previous two sections. "Percent Ticket Types" and "Percent Features" are from Tables 3 and 4, respectively. Commuter rail operators' applications shown in the upper right corner generally provide the most offerings in both ticket types and travel-related features. These leading apps include Metrolink, MTA eTix, MBTA mTicket, TriMet Tickets, and VRE Mobile. On the other hand, apps near the left and bottom of Figure 4, such as Coaster and Rio Ticketing, generally have fewer ticket types and app features. It should be noted that even though the Ventra app is displayed in the lower region of the graphic, this was solely based on ticket types and features available for the Metra portion of the app. The Ventra app offers many additional features for the Chicago Transit Authority and Pace bus system that were not considered in this analysis.

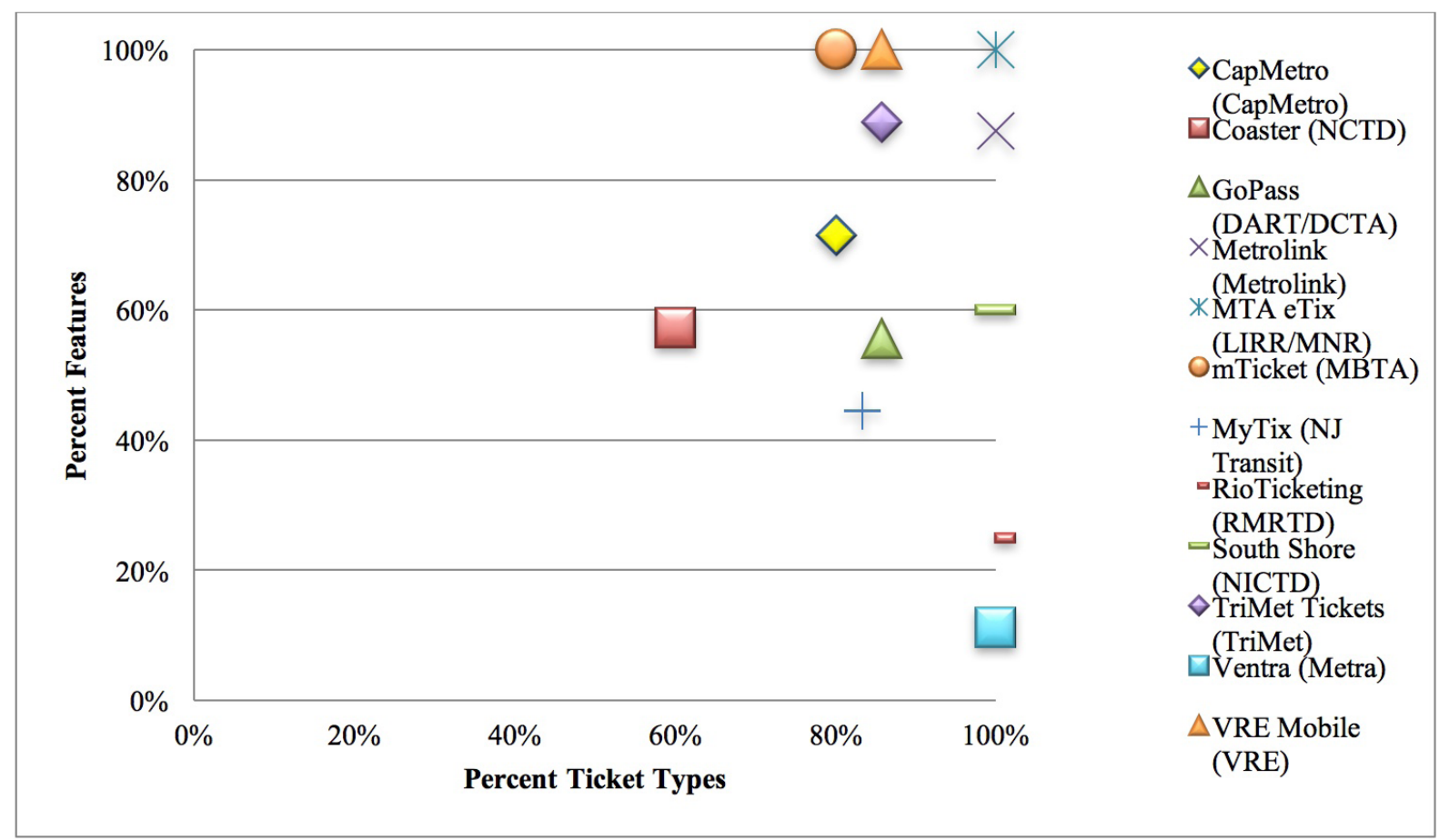

\section{FIGURE 4.}

Percent ticket types and application features offered 


\section{Dimension 4: Transfer Process}

Table 5 compares the agencies' fare policies related to transferring from commuter rail to an alternative form of nearby transit service, such as light rail, subway, or bus. The ability to transfer between modes using a mobile ticket is shown in the column labeled "In App" and the ability to transfer using traditional fare media is shown in the "Traditional" column. In Table 5, $Y$ indicates that the ticket purchase method enables a rider to transfer to a transit mode from commuter rail, $N$ designates that transferring to other modes is not available, and N/A denotes that there are no viable transfer alternatives when traveling on that system.

\section{TABLE 5.}

\section{Transfer Process}

\begin{tabular}{|c|c|c|c|}
\hline Application/Agency Name & In App & Traditional & Notes \\
\hline CapMetro (CapMetro) & $\mathrm{Y}$ & $\mathrm{Y}$ & \\
\hline Coaster (NCTD) & $\mathrm{N}^{*}$ & Y & $\begin{array}{l}\text { *Mobile does not include transfers to } \\
\text { San Diego Transit busses or trolleys. }\end{array}$ \\
\hline GoPass (DART/DCTA) & $\mathrm{Y}^{* *}$ & $\mathrm{Y}^{* *}$ & **Only DART allows transfers. \\
\hline Metrolink (Metrolink) & $\mathrm{N}$ & Y & \\
\hline MTA eTix (LIRR/MNR) & $\mathrm{N}$ & $Y^{* * *}$ & ***Available for a surcharge. \\
\hline mTicket (MBTA) & $\mathrm{N}$ & $\mathrm{Y}^{\varsigma}$ & ${ }^{\$}$ Available for monthly pass holders. \\
\hline MyTix (NJ Transit) & $\mathrm{N}$ & $\mathrm{N}$ & \\
\hline RioTicketing (RMRTD) & Y & Y & \\
\hline South Shore (NICTD) & $\mathrm{N} / \mathrm{A}$ & $\mathrm{N} / \mathrm{A}$ & No transit transfer options. \\
\hline TriMet Tickets (TriMet) & $\mathrm{Y}$ & $\mathrm{Y}$ & \\
\hline Ventra (Metra) & $Y^{* * *}$ & $Y^{* * *}$ & ${ }^{* * *}$ Available for a surcharge. \\
\hline VRE Mobile (VRE) & $Y^{\#}$ & $Y^{\#}$ & $\begin{array}{l}\text { \# VRE monthly holders can transfer to } \\
\text { local bus services only. }\end{array}$ \\
\hline
\end{tabular}

Key: $Y=$ Transfer to Transit Available; $N=$ Transfer to Transit Not Available

The results show that for the most part, traditional fare media offer greater transferability between commuter rail and nearby transit modes. Only three applications-CapMetro, RioTicketing, and TriMet Tickets-offered both in-app and traditional tickets with unrestricted transferability between commuter rail and nearby transit modes. The majority of the applications only offer transit transfers with traditional fare media, using select ticket types, or with stipulations or surcharges. In one case (South Shore), there were no nearby transfer options so N/A was used. Given the lack of integrated transfer policies using mobile ticketing at most of the commuter rail operators considered in this analysis, this area would benefit from future study.

\section{Conclusions}

In this paper, 12 mobile ticketing applications offered by the 14 largest commuter rail operators in the United States were qualitatively analyzed to synthesize the state of practice of mobile ticketing fare collection systems. The analysis focused on four dimensions, including the process for ticket validation, the ticket types provided in mobile apps, supplementary travel-related features available in mobile apps, and transfer policies. The first dimension revealed that all 12 mobile ticketing applications use visual inspection for validation, and 10 of the 12 also use QR barcodes to validate mobile tickets. The second dimension showed that 11 of the 12 applications 
offered at least $80 \%$ of the ticket types available using traditional fare media within the mobile applications. The third dimension revealed a large degree of variation in the availability of additional travel-related features, such as trip planners and schedules, in mobile ticketing apps. It is interesting to note that many apps examined in this analysis simply redirect users to the agency websites to access these additional tools. Last, examining the transfer policies in the mobile ticketing applications revealed that only 3 of the 12 apps have fully integrated transfers between commuter rail and other nearby transit modes.

In the future, additional research should analyze possible methods to increase the availability of transfers to other transit modes, such as subway, local bus, and streetcars, using mobile ticketing apps. This seamless connectivity could enhance the experience of commuter rail riders who use more than one transit mode to reach their destinations. Another topic for consideration in future research is whether $Q R$ codes are scanned by conductors/inspectors to meet a random quota or when ticket validity based on visual inspection is in question. Additionally, using backend data from mobile ticket purchases could be used in future research to explore commuter rail rider travel patterns, in a similar manner to research recently conducted on other modes of transit (Rahman, Wong, and Brakewood 2016). Last, this study considered mobile ticketing applications for commuter rail, but there are many other transit and shared transportation modes that use mobile apps for payment. Therefore, future studies could consider this widely expanding form of payment throughout the passenger transportation sector.

\section{References}

Ali, N., M. Touret, C. Brakewood, and R. Paaswell. 2017. "A Comparison of Transit Mobile Ticketing Applications in the United States and Europe." Presentation at Transportation Research Board 96th Annual Meeting. Washington, DC.

Brakewood, C., F. Rojas, J. Robin, J. Sion, and S. Jordan. 2014. “Forecasting Mobile Ticketing Adoption on Commuter Rail." Journal of Public Transportation 17 (1): 1-19.

Georggi, N., C. Brakewood, S. Barbeau, and A. Joslin. 2017. "A Concept of Operations for Deploying a Mobile Transit Fare Collection App." Presentation at Transportation Research Board 96th Annual Meeting. Washington, DC.

NCTD (North County Transit District). 2012. Coaster Tickets Can Now Be Purchased Online. June 6, 2012. http:// www.10news.com/news/coaster-tickets-can-now-be-purchased-online.

Neff, J., and M. Dickens. 2015. 2015 Public Transportation Fact Book, 66th Edition. Washington, DC: American Public Transportation Association.

Multisystems, Inc. 2003. Fare Policies, Structures and Technologies: Update. Transit Cooperative Research Program TCRP Report 94. Washington, DC: Transportation Research Board.

Rahman, S., J. Wong, and C. Brakewood. 2016. "Use of Mobile Ticketing Data to Estimate an Origin-Destination Matrix for New York City Ferry Service." Transportation Research Record: Journal of the Transportation Research Board 2544: 1-9. doi:10.3141/2544-01.

Sion, J., C. Brakewood, and O. Alvarado. 2016. "Planning for New Fare Payment Systems: An Equity Analysis of Smartphone, Credit Card, and Potential Mobile Ticketing Adoption by Bus Riders in Nassau County." Presentation at Transportation Research Board 95th Annual Meeting. Washington, DC.

SPX Corporation. 2016. "Rio Metro Ticketing." Apple App Store, Version 1.0.3. Retrieved from https://itunes. apple.com/us/app/rio-metro-ticketing/id1064171127?mt=8. 
Tavilla, E. 2015. Transit Mobile Payments: Driving Consumer Experience and Adoption. Federal Reserve Bank of Boston.

Tavilla, E. 2016. Commuting Gets a Little Easier with Transit Mobile Payments. Federal Reserve Bank of Boston.

Wallischeck, E. 2015. Preliminary Strategic Analysis of Next Generation Fare Payment Systems for Public Transportation. Transit Cooperative Research Program TCRP Report 177. Washington, DC: Transportation Research Board. doi:10.17226/22158.

\section{About the Authors}

Jonathan Mesoraca (jmesoraca11@gmail.com) is an assistant stationmaster with the Long Island Rail Road. He received a MEng in Transportation Engineering from the City College of New York and a BS in Construction Management from NYU Tandon School of Engineering.

Candace Brakewood (cbrakewo@utk.edu) is an assistant professor of Civil and Environmental Engineering at the University of Tennessee in Knoxville. She has a PhD in Civil Engineering from Georgia Institute of Technology, dual MS degrees in Transportation and Technology Policy from Massachusetts Institute of Technology, and a BS in Mechanical Engineering from Johns Hopkins University. 